\title{
ANALISIS EFISIENSI PENERAPAN TRANSAKSI NON TUNAI DALAM PENGELOLAAN KEUANGAN DAERAH PADA SEKRETARIAT DAERAH KOTA METRO PROVINSI LAMPUNG
}

\author{
Lidanna Dian Kurnia \\ Fakultas Ekonomi dan Bisnis, Universitas Muhammadiyah Metro \\ lidannadian@gmail.com
}

\begin{abstract}
ABSTRAK
Implementasi transaksi non tunai disetiap daerah berbeda-beda, baik kendala maupun penerapannya. Sistem transaksi non tunai dianggap lebih praktis, efisien, mudah, bahkan dapat mendukung perekonomian melalui peningkatan kecepatan peredaran uang. Adapun penerapan sistem non tunai ini merupakan salah satu bentuk untuk mewujudkan pengelolaan keuangan yang transparan, akuntabel, efektif dan efisien. Tujuan penelitian ini adalah mengetahui secara empiris efisiensi penerapan transaksi non tunai dalam pengelolaan keuangan daerah pada sekretariat daerah Kota Metro. Metode penelitian yang digunakan adalah metode deskriptif kuantitatif. Hasil penelitian menunjukan bahwa penerapan transaksi non tunai dalam pengelolaan keuangan daerah pada sekretariat daerah Kota Metro Provinsi Lampung memberikan banyak manfaat yaitu transaksi menjadi sangat efisien dan juga efektif. Keuntungan penerapan sistem transaksi non tunai yaitu penggunaan aliran dana seluruh transaksi dapat ditelusuri sehingga lebih akuntabel dikarenakan seluruh transaksi didukung dengan bukti yang sah; bendahara tidak harus memegang uang tunai dengan berbagai resiko kejahatan, kehilangan dan kesalahan hitung; menghindari penyalahgunaan keuangan di perangkat daerah; penggunaan anggaran lebih efisien dan arus keluar masuk kas lebih terkontrol; meningkatkan pengendalian internal pengelolaan kas dan mempermudah bendahara penerimaan penagihan. Selain itu, transaksi non-tunai cenderung lebih hemat biaya apabila dibandingkan penggunaan transaksi tunai dengan uang kartal alias uang kertas maupun uang logam dan mempercepat pelaksanaan tutup buku serta pelaporan keuangan dan dijamin kehandalannya.
\end{abstract}

Kata kunci: Efisiensi, Transaksi Non-Tunai

\begin{abstract}
Implementation of non-cash transactions in each region are different, both constraints and applications. The non-cash transaction system is considered to be more practical, efficient, easy, even able to support the economy through increased money circulation speed. The implementation of this non-cash system is one of the forms to realize the financial management that is transparent, accountable, effective and efficient. The aim of this study is empirically to know the efficiency of the implementation of non-cash transactions in regional financial management at Metro District. The research method used is a quantitative descriptive method. The results showed that the implementation of the non-cash transactions in regional financial management at Metro City, Lampung Province provides many benefits namely transactions become highly efficient and also effective. The advantage of implementing a non-cash transaction system is that the use of all transaction flows can be traced so that it is more accountable because all transactions are backed by valid proof; treasurer does not have to hold cash with varying risks of crime, loss and error counts; avoiding financial abuse in regional devices; more efficient usage of budgets and more controlled cash-in flows; improve internal control of cash management and simplify billing acceptance. In addition, non-cash transactions tend to be more cost-effective when compared to the use of cash transactions with kartal money, banknotes or coins and accelerate the implementation of book close as well as financial reporting and guaranteed reliability.
\end{abstract}

Keywords: Efficiency, Non-Cash Transactions 


\section{PENDAHULUAN}

Penerapan Transaksi Non Tunai dalam pengelolaan keuangan daerah sangat diperlukan untuk mempermudah proses pertanggungjawaban keuangan perangkat daerah dan juga langkah pemerintah untuk mencegah resiko terjadinya penyalahgunaan keuangan di Pemerintah Daerah oleh oknum-oknum yang tidak bertanggungjawab, walaupun pada kenyataannya juga masih terdapat penyimpangan pada keuangan daerah meskipun sudah menggunkan Transaksi Non Tunai.

Selain itu, sistem Transaksi Non Tunai dianggap lebih praktis, efisien, mudah, bahkan dapat mendukung perekonomian melalui peningkatan kecepatan peredaran uang. Adapun penerapan sistem non tunai ini merupakan salah satu bentuk untuk mewujudkan pengelolaan keuangan yang transparan, akuntabel, efektif dan efisien.

Sekretariat Daerah Kota Metro merupakan salah satu Organisasi Perangkat Daerah (OPD) yang siap dan tidak siap harus siap mengimplementasikan Transaksi Non Tunai, demi terciptanya akuntabilitas, transparansi, efektifitas dan efisiensi anggaran dalam pemerintahan. Transaksi Non Tunai adalah memindahkan bertransaksi dengan menggunakan uang tunai menjadi pemindahbukuan antar rekening baik antara Bank yang ditunjuk sebagai Bank Pengelola Kas Daerah maupun dengan Bank Umum lainnya, oleh karena itu kesiapan Bank yang ditunjuk sebagai pengelola Kas Daerah untuk menyiapkan fitur-fitur aplikasi yang lebih memudahkan dalam bertransaksi secara non tunai baik yang dilaksanakan melalui mesin ATM, aplikasi via Handphone maupun bertransaksi dengan menggunakan fasilitas Bank lainnya yang bisa dikoneksikan ke Bank Daerah sebagai pengelola Kas Daerah, penyediaan sarana prasarana seperti Kartu ATM, Mesin ATM, sumberdaya manusia yang berfungsi sebagai operator Transaksi Non Tunai.

Sebelum pelaksanaan transaksi non tunai terdapat kendala-kendala yang dihadapi dalam pengelolaan keuangan khususnya pada OPD Sekretariat Derah Kota Metro diantaranya:

A. Keamanan

Dalam pelaksanaan transaksi tunai khususnya pada OPD Sekretariat Derah Kota Metro, Bendahara memegang uang tunai dalam jumlah yang besar dan setiap membayarkan kegiatan selalu dalam bentuk uang tunai, hal ini rawan akan terjadinya tindakan kriminal, dengan memegang uang tunai rawan terjadi tindakan korupsi seperti pengurangan jumlah uang, ketepatan jumlah uang dan peredaran uang palsu.

B. Kecepatan dalam pembuatan laporan keuangan

Dalam prakteknya setiap pembuatan laporan keuangan membutuhkan banyak Sumberdaya Manusia khususnya dalam pengintegrasian laporan-laporan dimana transaksi tercatat terpisah dan masih bersifat manual dengan perhitungan real uang yang ada dibendahara sehingga membu-tuhkan waktu dalam pembuatan laporan keuangan.

C. Transaksi keuangan terbatas

Transaksi keuangan terbatas khususnya dalam penarikan uang hanya dapat dilakukan pada Bank Pengelola Kas Daerah sehingga transaksi tidak dapat dilakukan pada hari libur dan hanya dapat dilakukan pada Bank tersebut.

Dalam pengimplementasian pengelolaan keuangan daerah dengan menggunakan Transaksi Non Tunai pada Sekretariat Daerah Kota Metro mengalami beberapa kendala, di antaranya adalah:

A. Masalah sumber daya manusia (SDM) pengelola keuangan; Masih 
lemahnya sumberdaya manusia yang terlibat dalam proses pengelolaan keuangan daerah khususnya dalam memahami penggunaan Sistem Informasi Manajemen Keuangan Daerah (SIMDA).

B. Masalah Peraturan Perundangundangan; Berbagai peraturan yang berkaitan dengan pengelolaan keuangan daerah masih mempunyai potensi multitafsir sehingga menimbulkan banyak persepsi mengenai tatalaksana keuangan daerah.

C. Masalah Infrastruktur; Penerapan SIMDA memerlukan akses internet yang baik di seluruh wilayah Organisasi Perangkat Daerah (OPD) berada, karena SIMDA secara online mengharuskan seluruh proses keuangan daerah dilaksanakan secara online, untuk itu fasilitas pendukung proses keuangan secara online tersebut harus tersedia dengan baik.

Pengimplementasian Transaksi Non Tunai disetiap daerah berbeda-beda, baik kendala maupun penerapannya. Penelitian terdahulu telah banyak dilakukan yang berkaitan dengan penerapan Transaksi Non Tunai dalam pengelolaan keuangan daerah, seperti penelitian yang telah dilakukan oleh Selly Septiani dan Endah Kusumastuti (2018), dengan judul "Penerapan Transaksi Non Tunai Dalam Pelaksanaan Belanja Pemerintah Daerah Untuk Mewujudkan Prinsip Good governance (Studi Kasus Pada Badan Pengelolaan Keuangan Dan Aset Daerah Pemerintah Provinsi Jawa Barat)". Tujuan dari penelitian ini untuk mengetahui prosedur pembayaran secara non tunai dan untuk mengetahui implementasi Transaksi Non Tunai berdasarkan prinsip Good governance dalam pelaksanaan belanja Pemerintah Daerah di BPKAD Pemerintah Provinsi Jawa Barat. Peneliti menggunakan metode penelitian berupa wawancara, observasi, studi kepustakaan dan dokumentasi. Peneliti menggunakan data primer yaitu hasil dari wawancara dengan narasumber terkait.

Hasil penelitian menunjukan penerapan Transaksi Non Tunai ini dirasakan dapat meningkatkan perwujudan prinsip Good governance terutama prinsip akuntabilitas, transparansi, efektivitas dan efisiensi. Dengan adanya penerapan Transaksi Non Tunai dalam pelaksanaan belanja pemerintah dapat menekan tingkat penyelewengan terutama korupsi.

Dari penelitian di atas dapat diketahui bahwa penerapan Transaksi Non Tunai ini dirasakan dapat meningkatkan perwujudan prinsip Good governance terutama prinsip akuntabilitas, transparansi, efektivitas dan efisiensi. Dengan adanya penerapan Transaksi Non Tunai dalam pelaksanaan belanja pemerintah dapat menekan tingkat penyelewengan terutama korupsi. penggunaan aliran dana seluruh transaksi dapat ditelusuri sehingga lebih akuntabel, dikarenakan seluruh transaksi didukung dengan bukti yang sah; bendahara tidak harus memegang uang tunai dengan berbagai resiko kejahatan, kehilangan, dan kesalahan hitung; menghindari penyalahgunaan keuangan di perangkat daerah; penggunaan anggaran lebih efisien dan arus keluar masuk kas lebih terkontrol; meningkatkan pengendalian internal pengelolaan kas; dan mempermudah bendahara penerimaan dalam penagihan retribusi kebersihan, karna sebagian penagihannya sudah langsung dibayarkan oleh wajib retribusi lewat bank atau rekening.

Berdasarkan uraian latar belakang di atas, maka dalam penelitian ini penulis tertarik untuk mengambil judul "Analisis Efisiensi Penerapan Transaksi Non Tunai Dalam Pengelolaan Keuangan Daerah Pada Sekretariat Daerah Kota Metro Provinsi Lampung".

\section{A. Tujuan Penelitian}


Penelitian ini bertujuan untuk mengetahui secara empiris:

1. Efisiensi Penerapan Transaksi Non Tunai Dalam Pengelolaan Keuangan Daerah Pada Sekretariat Daerah Kota Metro.

2. Faktor penghambat Penerapan Transaksi Non Tunai Dalam Pengelolaan Keuangan Daerah Pada Sekretariat Daerah Kota Metro.

3. Faktor pendukung Penerapan Transaksi Non Tunai Dalam Pengelolaan Keuangan Daerah Pada Sekretariat Daerah Kota Metro.

\section{B. Transaksi Non Tunai}

"Sistem pembayaran dan pola bertransaksi ekonomi terus mengalami perubahan. Kemajuan teknologi dalam sistem pembayaran menggeser peranan uang tunai (currency) sebagai alat pembayaran non tunai yang lebih efisien dan ekonomis" (Pramono, dalam Dona dan Khaidir, 2018: 60).

Harahap (2018: 2) menyatakan "Transaksi non tunai merupakan perwujudan dari sistem Alat Pembayaran Menggunakan Kartu (APMK) yang dilayani sistem perbankan, dunia perbankan secara tidak langsung menciptakan inovasi teknologi baru dalam sistem pembayaran".

Dalam Edaran Menteri Dalam Negeri No 910/1867/SJ tentang implementasi Transaksi Non Tunai pada pemerintah daerah, dinyatakan sebagai berikut: "Transaksi Non Tunai merupakan pemindahan sejumlah nilai uang dari satu pihak ke pihak lain dengan menggunakan instrument berupa Alat pembayaran Menggunakan Kartu (APMK), cek, bilyet giro, uang elektronik atau sejenisnya".
Bank Indonesia (dalam Mongisidi, 2019: 5) disebutkan "Transaksi non tunai adalah pembayaran yang memanfaatkan teknologi informasi dan komunikasi. Pelaksanaan Transaksi non tunai dapat dilakukan melalui sistem pembayaran online seperti transfer melalui Real Time Gross Settlement (RTGS), APMK, e-money, dan electronic channel lainnya".

Menurut Alam dan Rudianto (2013: 177) mengemukakanan: "Alat pembayaran non tunai sudah berkembang dan semakin lazim di pakai masyarakat. Alat pembayaran non tunai memerlukan penggunaaan satu atau lebih bank untuk menyelesaikan transaksi. Pembayaran non tunai tidak tercapai hanya dengan bertukar alat pembayaran, tetapi perlu ada transfer uang deposit antarbank pembayar dan penerima pembayaran. Instrumen pembayaran non tunai menyediakan mekanisme bagi bank untuk transfer antar bank".

Adapun menurut Astuti (2018:

10) mengemukakan: "Sistem pembayaran non tunai melibatkan lembaga perantara agar dana yang ditransaksikan dapat benar-benar efektif berpindah dari pihak yang menyerahkan kepada pihak penerima. Jika pihak-pihak tersebut dalam lingkaran bank yang sama, maka bank tersebut hanya cukup melakukan proses pemindahbukuan dari rekening yang satu ke rekening lainnya. Namun jika kedua belah pihak tersebut tidak dalam satu lingkar bank yang sama, maka diperlukan lembaga kliring yakni Bank Indonesia untuk mengakomodir transaksi tersebut".

Dari beberapa defisini di atas dapat disintesiskan bahwa transaksi non tunai adalah pemindahan sejumlah nilai uang dari satu pihak ke pihak lain dengan memanfaatkan teknologi informasi dan komunikasi. 
Pelaksanaan Transaksi non tunai dapat dilakukan melalui sistem pembayaran online seperti transfer melalui Real Time Gross Settlement (RTGS), APMK, e-money, dan electronic channel lainnya".

\section{Fungsi dan Tujuan Transaksi Non Tunai}

Menurut Hancock dan Humphey (1998: 1575) pada umumnya transaksi yang menggunakan sistem pembayaran elektronis berbiaya hanya antara sepertiga sampai separuh dari transaksi yang menggunakan sistem pembayaran berbasis kertas, sehingga penghematan substansial dalam pengeluaran dapat direalisasi melalui perubahan sistem dari yang berbasis kertas ke sistem yang bersifat elektronis dan dapat menstimulus pertumbuhan ekonomi, oleh sebab itu bagian internal dari sistem pembayaran elektronik ialah Alat pembayaran dengan Menggunakan Kartu (APMK) yang banyak digunakan oleh masyarakat banyak. Pengunaan alat pembayaran ini memberikan manfaat yang sangat besar bagi berbagai sektor perekonomian.

\section{Manfaat Transaksi Non Tunai}

Manfaat transaksi non tunai dalam Surat Edaran Menteri Dalam Negeri No 910/1867/SJ dan sesuai Peraturan Presiden tahun 2016 tentang pencegahan korupsi, yaitu:
a. Mendorong transparansi dan akuntabilitas pengelolaan keuangan daerah
b. Mencegah peredaran uang palsu
c. Menghemat pengeluaran Negara
d. Menekan laju inflasi
e. Mencegah transaksi illegal (korupsi)

f. Meningkatkan sirkulasi uang dalam perekonomian (velocity of money)

g. Mewujudkan tertib administrasi pengelolaan kas.

E. Aplikasi pendukung pelaksanaan Transaksi Non Tunai pada Pengelolaan Keuangan Daerah Pemerintah Kota Metro

Dalam penerapan Transaksi Non Tunai pada Pemerintah Kota Metro memerlukan aplikasi pendukung pengelolaan keuangan, ada beberapa aplikasi pengelolaan keuangan yang sudah diterapkan sebelum pelaksanaan Transaksi Non Tunai yaitu Sistem Informasi Manajemen Daerah (SIMDA) Keuangan dan Pemerintah Daerah Online (PEMDA ONLINE).

1. Sistem Informasi Manajemen Daerah (SIMDA) Keuangan Sebuah aplikasi pengelolaan keuangan daerah yang dibangun dan dikembangkan oleh Badan Pengawas Keuangan dan Pembangunan (BPKP) yang bekerjasama dengan Pemerintah Daerah, Aplikasi SIMDA dapat dimplemetasikan untuk pengelolaan keuangan daerah secara terintegrasi, menggunakan teknologi multi user dan teknologi client/server, dari penyusunan anggaran, pelaksanaan anggaran, dan pertanggungjawaban keuangan baik dilaksanakan di SKPKD (Satuan Kerja Pengelola Keuangan Daerah) maupun di OPD (Organisasi Perangkat Daerah) lainnya selaku pengguna anggaran, sehingga mempunyai keuntungan:

Pengendalian transaksi
terjamin sesuai dengan
peraturan yang ada; 
b. Efisien dalam melakukan penatausahaan, hanya membutuhkan satu kali input data transaksi sehingga menghemat waktu, tenaga dan biaya;

c. Cepat, akurat dan efisien dalam menghasilkan informasi keuangan.

Tujuan pengembangan

Program Aplikasi Sistem Informasi Manajemen Daerah ini adalah:

a. Menyediakan Data base mengenai kondisi di daerah yang terpadu baik dari aspek keuangan, aset daerah, kepegawaian/aparatur daerah maupun pelayanan publik yang dapat digunakan untuk penilaian kinerja instansi pemerintah daerah.

b. Menghasilkan informasi yang komprehensif, tepat dan akurat kepada manajemen pemerintah daerah. Informasi ini dapat digunakan sebagai bahan untuk mengambil keputusan.

c. Mempersiapkan aparat daerah untuk mencapai tingkat penguasaan dan pendayagunaan teknologi informasi yang lebih baik.

d. Memperkuat basis pemerintah daerah dalam melaksanakan otonomi daerah.

2. Pemerintah Daerah Online (Pemda Online) PT. Bank Lampung

Pemerintah Daerah Online (Pemda Online) adalah suatu sistem aplikasi yang dibangun dan dikembangkan oleh PT. Bank Lampung selaku Bank penempatan kas daerah yang ditunjuk secara resmi oleh
Pemerintah Daerah dalam hal ini Pemerintah Kota Metro.

Aplikasi ini menghubungkan Bank Lampung dengan Organisasi Perangkat Daerah (OPD) dengan tujuan mendukung kegiatan transaksi dan laporan mutasi keuangan atas rekening OPD di Bank Lampung. Melalui aplikasi ini, maka transaksi dan laporan mutasi keungan atas rekening nasabah tidak perlu dilakukan di kantor Bank Lampung tetapi dapat dilakukan dimana saja dan kapan saja.

Selain itu pengembangan atas aplikasi ini terus dilakukan, diantaranya dengan membangun fitur Pemda Online yang dapat berjalan pada Handphone berbasis Android, sehingga kapanpun diingkan nasabah Bank Lampung terkait mutasi atas rekening, saldo rekening atapun transaksi lainnya seperti pembelian pulsa dan pembayaran tagihan atas kebutuhan rumah tangga dapat dilakukan dengan menggunakan aplikasi Pemda Online.

\section{F. Good governance}

1. Pengertian Good governance

Menurut United Nations

Development Program (UNDP) (dalam Dwiyanto, 2005: 82) "Good governance adalah tata kelola pemerintahan yang baik, sebagai hubungan yang sinergis dan konstruktif di antar negara, sektor swasta, dan society.

Menurut Ganie (2000:142) pengertian good governance, sebagai berikut: "Good governance adalah mekanisme pengelolaan sumber daya ekonomi dan sosial yang melibatkan pengaruh sektor 
Negara dan sektor non-Negara dalam suatu usaha kolektif".

Sedangkan menurut World Bank (dalam Mardiasmo, 2009: 18) mendefinisikan: "good governance sebagai suatu penyelenggaraan manajemen pembangunan yang solid dan bertanggung jawab yang sejalan dengan prinsip demokrasi dan pasar yang efisien, penghindaran salah alokasi dana investasi, dan pencegahan korupsi baik secara politik maupun administratif menjalankan disiplin anggaran serta penciptaan legal and political framework bagi tumbuhnya aktivitas usaha"

Definisi good governance menurut LAN (2001: 6), yaitu: "Penyelenggaraan pemerintah negara yang solid dan bertanggungjawab, serta efisien dan efektif, dengan menjaga kesinergian interaksi yang konstruktif diantara domain-domain negara, sektor swasta dan masyarakat (society)".

Hughes dan Ferlie (dalam

Osborne dan Gaebler, 1992) menyatakan "Good governance memiliki kriteria yang berkemampuan untuk memacu kompetisi, akuntabilitas, responsip terhadap perubahan, transparan, berpegang pada aturan hukum”.

Dari beberapa pendapat di atas dapat di sintesiskan bahwa Good governance adalah tata kelola pemerintahan yang baik, bersinergis untuk mengelola sumber daya yang dimiliki suatu Negara secara efektif, efisien, akuntabilitas dan tranparan untuk kepentingan masyarakat.

\section{Prinsip-Prinsip Good governance Menurut Lembaga} Administrasi Negara (2000: 7) prinsip - prinsip Good governance, sebagai berikut:

a. Partisipasi masyarakat b. Tegaknya Supremasi Hukum

c. Transparansi

d. Peduli pada Stakeholder

e. Berorientasi pada Kasus

f. Kesetaraan

g. Efektivitas dan Efisien

h. Akuntabilitas

i. Visi Strategis.

Sedangkan menurut Ganie (2000: 145) Prinsip - prinsip good governance yaitu:

a. Akuntabilitas publik

b. Value for money

c. Transparansi

d. Efektivitas manajemen sumber daya manusia

\section{G. Hasil Penelitian yang Relevan}

1. Angelina Pelealu, Grace B. Nangoi, Natalia Y.T. Gerungai (2018)

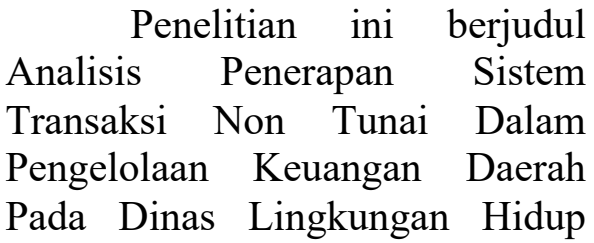
Kota Bitung dalam penelitiannya Tujuan dari penelitian adalah untuk mengetahui kesiapan proses penerapan sistem Transaksi Non Tunai dalam pengelolaan keuangan daerah di Badan Lingkungan Kota Bitung dan untuk mengetahui hambatan apa saja yang terjadi dalam proses pelaksanaan Transaksi Non Tunai di Indonesia. manajemen keuangan regional di Layanan Lingkungan Kota Bitung. Metode penelitian yang digunakan adalah deskriptif kualitatif.

Hasil penelitian, yaitu Kantor Lingkungan Hidup Kota Bitung telah menerapkan sistem Transaksi Non Tunai secara bertahap dalam APBD berdasarkan Surat Edaran Menteri Dalam Negeri No. 910/1866 / SJ. Kendala yang dihadapi adalah 
proses administrasi terkadang terhambat, proses sosialisasi, penerapannya hingga penerimaan pungutan dengan nilai nominal kecil. Keuntungan penerapan sistem Transaksi Non Tunai di Dinas Lingkungan Hidup kota Bitung yaitu, penggunaan aliran dana seluruh transaksi dapat ditelusuri sehingga lebih akuntabel, dikarenakan seluruh transaksi didukung dengan bukti yang sah; bendahara tidak harus memegang uang tunai dengan berbagai resiko kejahatan, kehilangan, dan kesalahan hitung; menghindari penyalahgunaan keuangan di perangkat daerah; penggunaan anggaran lebih efisien dan arus keluar masuk kas lebih terkontrol; meningkatkan pengendalian internal pengelolaan kas; dan mempermudah bendahara penerimaan dalam penagihan retribusi kebersihan, karna sebagian penagihannya sudah langsung dibayarkan oleh wajib retribusi lewat bank atau rekening.

2. Selly Septiani, Endah Kusumastuti (2018)

Judul penelitian yakni Penerapan Transaksi Non Tunai Dalam Pelaksanaan Belanja Pemerintah Daerah Untuk Mewujudkan Prinsip Good governance (Studi Kasus Pada Badan Pengelolaan Keuangan Dan Aset Daerah Pemerintah Provinsi Jawa Barat). Tujuan dari penelitian ini untuk mengetahui prosedur pembayaran secara non tunai dan untuk mengetahui implementasi Transaksi Non Tunai. Berdasarkan prinsip Good governance dalam pelaksanaan belanja Pemerintah Daerah di BPKAD Pemerintah Provinsi Jawa Barat. Peneliti menggunakan metode penelitian berupa wawancara, observasi, studi kepustakaan dan dokumentasi. Peneliti menggunakan data primer yaitu hasil dari wawancara dengan narasumber terkait.

Hasil penelitian menunjukan penerapan Transaksi Non Tunai ini dirasakan dapat meningkatkan perwujudan prinsip Good governance terutama prinsip akuntabilitas, transparansi, efektivitas dan efisiensi. Dengan adanya penerapan Transaksi Non Tunai dalam pelaksanaan belanja pemerintah dapat menekan tingkat penyelewengan terutama korupsi.

3. Utari dan Salomo (2017)

Judul penelitian "Analisa Pelaksanaan Transaksi Non Tunai (Non Cash) berdasarkan Prinsip Good governance di Pemerintah Provinsi DKI Jakarta. Membahas tentang analisa pelaksanaan Transaksi Non Tunai berdasarkan prinsip Good governance di Pemerintah Provinsi DKI Jakarta. Prinsip Good governance yang dibahas yaitu akuntabilitas, transparasi dan berlandaskan hukum.

Hasil Penelitian ini menunjukkan bahwa proses implementasi non tunai di Pemerintah Provinsi DKI Jakarta dimulai secara penuh di tahun 2016 meliputi penerimaan dan pengeluaran APBD. Pelaksanaan mekanisme non tunai yang dilakukan sudah berdasarkan good governance tetapi belum sempurna karena yang dilakukan oleh Pemerintah Provisi DKI Jakarta masih dalam tahap pengembangan sehingga tetap masih perlunya dukungan pihakpihak yang membantu Pemprov DKI tidak hanya dari sektor 
perbankan melainkan dari stakeholder/vendor/pihak ketiga serta masyarakat turut mensukseskan keberhasilan dalam implementasi non tunai ini. Teori 7S Mc Kinsey dipergunakan untuk membuktikan bahwa berbagai aspek seperti strategi, struktur, sistem, skill \& staffing serta style \& shared value kesemuanya berperan penting dalam keberhasilan implementasi program mekanisme non tunai ini.

\section{METODE PENELITIAN}

Penelitian ini merupakan penelitian yang bertujuan menjelaskan fenomena yang ada dengan menggunakan angkaangka untuk mencandarkan karakteristik individu atau kelompok (Syamsudin \& Damiyanti: 2011). Penelitian ini menilai sifat dari kondisi-kondisi yang tampak. Tujuan dalam penelitian ini dibatasi untuk menggambarkan karakteristik sesuatu sebagaimana adanya.

\section{A. Populasi, Sampel dan Teknik Sampling \\ "Populasi adalah wilayah} generalisasi yang terdiri atas objek atau subyek yang mempunyai kualitas dan karakteristik tertentu yang ditetapkan oleh peneliti untuk dipelajari dan kemudian ditarik kesimpulannya" (Sugiyono, 2016: 80). Populasi dalam penelitian ini adalah seluruh Aparatur Sipil Negara (ASN) pada Sekretariat Daerah Kota Metro yang berjumlah 153. Dalam penelitian ini sampel diambil dengan menggunakan teknik Purposive Sampling. Menurut Sugiyono (2016: 85) "purposive sampling adalah teknik pengambilan sampel sumber data dengan pertimbangan tertentu." Alasan menggunakan teknik Purposive Sampling adalah karena tidak semua responden memiliki kriteria yang sesuai dengan fenomena yang diteliti. Oleh karena itu, penulis memilih teknik Purposive Sampling yang menetapkan pertimbanganpertimbangan atau kriteria-kriteria tertentu yang harus dipenuhi oleh sampel yang akan dijadikan responden dalam penelitian ini. Jumlah sampel dalam penelitian ini adalah 30 responden.

\section{B. Analisis Data}

Penelitian ini merupakan penelitian yang bertujuan menjelaskan fenomena yang ada dengan menggunakan angka-angka untuk mencandarkan karakteristik individu atau kelompok (Syamsudin \& Damiyanti: 2011). Penelitian ini menilai sifat dari kondisi-kondisi yang tampak. Tujuan dalam penelitian ini dibatasi untuk menggambarkan karakteristik sesuatu sebagaimana adanya.

Metode analisis yang digunakan dalam penelitian ini adalah analisis deskriptif persentase. Metode ini digunakan untuk mengkaji variabel yang ada pada penelitian yaitu Efisiensi Penerapan Transaksi Non Tunai Dalam Pengelolaan Keuangan Daerah Pada Sekretariat Daerah Kota Metro Provinsi Lampung. Deskriptif persentase ini diolah dengan cara frekuensi dibagi dengan jumlah responden dikali 100 $\%$, seperti dikemukan Sudjana (2001: 128) adalah sebagai berikut:

$\mathrm{P}=(\mathrm{F} / \mathrm{N}) \times 100 \%$

Keterangan:

$\mathrm{P}$ : Presentase jawaban

$\mathrm{F}$ : Frekuensi nilai yang diperoleh dari seluruh item

$\mathrm{N}$ : Jumlah responden

$100 \%$ : Bilangan tetap

Dalam penelitian ini yang menggunakan rumus presentase adalah jawaban dari kuesioner yang telah disebar, kemudian masingmasing jawaban di analisis dengan 
rumus presentase yaitu banyaknya jawaban dibagi dengan jumlah keseluruhan responden kemudian dikali dengan bilanngan tetap yaitu $100 \%$.

\section{HASIL DAN PEMBAHASAN}

Efisiensi Penerapan Transaksi Non Tunai Dalam Pengelolaan Keuangan Daerah Pada Sekretariat Daerah diukur menggunakan beberapa indikator, hasil analisis yang berkaitan dengan indikator adalah sebagai berikut:

\section{A. Efisiensi}

Dari hasil penelitian di atas secara garis besar dapat disimpulkan bahwa penerapan transaksi non tunai dalam pengelolaan Keuangan Daerah pada Sekretariat Daerah Kota Metro adalah efisien. Dari empat indikator yang peneliti gunakan untuk mengukur efisien atau tidaknya penerapan transaksi non tunai dalam pengelolaan Keuangan Daerah pada Sekretariat Daerah Kota Metro menunjukkan hasil efisien semua. Adapun perinciannya sebagai berikut:

\section{Cepat}

Semenjak menggunakan transaksi non tunai, penyelesaian pekerjaan menjadi lebih cepat. Hal ini dapat dilihat berdasarkan pernyataan bahwa responden menjawab sangat setuju dan setuju sebanyak $63,3 \%$. Para pengguna transaksi non tunai merasakan manfaat dari transaksi non tunai yakni pekerjaan mereka menjadi lebih cepat selesai.

$$
\text { Penggunaan transaksi }
$$

nontunai juga lebih mempercepat pelaksanaan tutup buku serta pelaporan keuangan dan dijamin kehandalannya. Hal tersebut didukung oleh hasil jawaban kuisinoner responden dengan jawaban sangat setuju dan setuju sebanyak $60 \%$. Pegawai Sekretariat Daerah Kota Metro merasakan bahwa semenjak menggunakan transaksi nontunai lebih mempercepat pelaksanaan tutup buku serta pelaporan keuangan dan dijamin kehandalannya.

Penggunaan transaksi non tunai memudahkan dan mempercepat pelaksanaan setoran/tagihan dalam pengelolaan Keuangan Daerah. Hal ini didukung oleh jawaban responden yang menjawab sangat setuju dan setuju sebanyak $53,3 \%$. Salah satu manfaat adanya transaksi nontunai adalah Memudahkan dan mempercepat pelaksanaan setoran/tagihan. Prosedur penarikan uang secara tunai tidak dapat dilakukan secara langsung, tetapi harus menggunakan cek terlebih dahulu ke bank setelah itu pengambilan uang tunai terjadi proses pembayaran. Proses seperti itu memperlama waktu, berbeda dengan transaksi nontunai, yang bisa dilakukan kapanpun dan dimanapun.

Hasil pekerjaan dapat ditingkatkan dengan menggunakan transaksi nontunai. Hasil tersebut didukung oleh hasil kuisioner, responden menjawab dengan sangat setuju dan setuju sebanyak 63,3\%. Dengan adanya transaksi nontunai, maka akan mempercepat waktu transaksi sehingga responden dapat menggunakan waktunya untuk meningkatkan pekerjaan.

2. Akurat

Hasil pekerjaan menjadi lebih akurat dengan menggunakan transaksi nontunai. Hal ini didukung oleh jawaban responden yang memilih sangat setuju dan setuju sebanyak 53,3\%. Tidak perlu diragukan lagi ketika menggunakan transaksi nontunai 
akan menjadikan hasil kerja lebih akurat karena sistemnya yang konvensional, bukan manual.

Penggunaan transaski non tunai meningkatkan kedisiplinan, pengelola keuangan daerah dalam melakukan pencatatan dapat meminimalisir kesalahan. Hal ini didukung oleh jawaban responden yang memilih sangat setuju dan setuju sebanyak $63,3 \%$. Pemeriksa keuangan tidak mengalami kesulitan lagi dalam memeriksa, cukup dengan melihat rekening koran. Dari rekening koran akan terlihat alur uang yang masuk dan keluar dengan sedikit kesalahan.

Penggunaan aliran dana seluruh transaksi dapat ditelusuri sehingga lebih akuntabel, dikarenakan seluruh transaksi didukung dengan bukti yang sah. Hal ini didukung oleh jawaban responden yang menjawab sangat setuju dan setuju sebanyak $63,3 \%$. Penggunaan aliran dana seluruh transaksi dapat ditelusuri sehingga lebih akuntabel, dikarenakan seluruh transaksi didukung dengan bukti yang sah, dengan sudah adanya penerapan transaksi non tunai ini secara tidak langsung setiap alur keluar masuk anggaran sudah dapat diketahui oleh publik. Dengan adanya jejak digital atau jejak bukti transfer yang terekam di perbankan, segala macam transaksi menjadi lebih transparan terlihat jelas aliran uangnya.

Dengan penggunaan transaksi non tunai, pengendalian internal terhadap pengelolaan kas meningkat. Hal ini didukung oleh jawaban responden yang menjawab sangat setuju dan setuju sebanyak 63,3\%. Pengendalian internal terhadap pengelolaan kas meningkat, sebelum dilaksananakannya transaksi non tunai masih terjadi uang tunai yang beredar itu tidak akuntabel, transaksi tidak dapat dikendalikan. Maka maksud dari pertanggungjawabannya yaitu saat melakukan transaksi dengan menggunakan uang tunai dimungkinkan terjadinya SPJ fiktif. Uangnya tidak sampai atau transaksi yang sebenarnya tidak sesuai dengan kwitansi. Namun semenjak adanya transaksi nontunai, mempermudah pengendalian transaksi dan pengelolaan kas meningkat.

3. Murah

Biaya transaksi non tunai terjangkau, Hal ini didukung oleh jawaban responden yang menjawab sangat setuju dan setuju sebanyak 73,3\%. Dengan penggunaan transaksi non tunai tidak perlu mengerluakan uang transport ketika akan mengirimkan dana dan lain-lain.

Transaksi non tunai cenderung lebih hemat biaya apabila dibandingkan penggunaan transaksi tunai dengan uang kartal, alias uang kertas maupun uang logam. Hal tersebut di respon positif oleh responden, terbukti yang menjawab sangat setuju dan setuju sebanyak $60 \%$.

Dari sisi efisiensi, transaksi non tunai ini dirasa dapat meningkatkan efisiensi. Dengan adanya transaksi non tunai dapat melakukan beberapa transaksi transfer satu kali. Artinya dengan adanya transaksi non tunai, penggunaan anggaran lebih efisien dan arus keluar masuk kas lebih terkontrol Hal ini didukung oleh responden yang menjawab sangat setuju dan setuju sebanyak $66,7 \%$.

Penggunaan transaksi non tunai menyebabkan efisiensi biaya dan waktu. Transkasi lebih cepat 
sehingga menghemat waktu dan biaya, sehingga tidak perlu lagi untuk mengantri di Bank, ketika masih menggunakan SI/ Standing Intruction itu masih mengantri, kita buat disini beberapa lembar baru kita minta tanda tangan BPP dan KPA baru nanti ngantri ke bank. Responden memnjawab sangat setuju dan setuju sebanyak $66,7 \%$.

4. Mudah

tunai mempermudah mutasi keuangan karena dapat dilakukan dimanapun dan kapanpun. Hal ini didukung oleh jawaban responden yang menjawab sangat setuju dan setuju sebanyak $76,7 \%$. Selain itu penerapan transaksi non tunai juga dapat dengan mudah melihat informasi saldo dan mutasi dari seluruh transaksi dapat ditelusuri serta didukung bukti yang sah sehingga lebih akuntabel. Pada akhir tahun anggaran bendahara merasa terbantu dengan adanya transaksi non tunai ini karena memberikan kemudahan dalam membuat laporan pertanggungjawaban secara akurat dan tepat waktu.

Dengan penggunaan transaksi non tunai, bendahara dan para pegawai tidak harus memegang uang tunai dengan berbagai resiko kejahatan, kehilangan, dan kesalahan hitung. Hal ini direspon positif oleh para responden dengan yakni sangat setuju dan setuju sebanyak $76,7 \%$. Pelaksanaan pembayaran dengan tunai lebih beresiko, seperti ketika mengambil uang tunai di bank ke kantor terdapat resiko kehilangan. Ketika disimpan di brankas, dimungkinkan adanya resiko kehilangan. Ketika menyerahkan uang ke pengusaha dimungkinkan adanya resiko lagi.

Dengan penggunaan

transaksi non tunai, Transaksi dapat dengan mudah ditelusuri, transaski non tunai diantaranya memastikan seluruh transaski didukung bukti yang sah dan aliran dana dapat ditelusuri, mencegah pengambilan dana secara tidak sah, dan mencegah terjadinya manipulasi pertanggungjawaban belanja. Responden sangat setuju sebanyak dan setuju sebanyak $80 \%$.

\section{B. Faktor Penghambat Penerapan Transaksi Non Tunai}

Dari hasil wawancara dengan pegawai pengelola Keuangan Daerah tentang faktor penghambat penerapan transaksi non tunai yakni sulit menerapkan sistem transaksi non tunai pada penerimaan yang jumlahnya kecil. Selain itu masalah internal dalam pembuatan SPTD yang mengalami keterlambatan disebabkan karena dokumen pendukung pembuatan SPTD yang belum lengkap pada saat proses pembuatan SPTD. Untuk masalah eksternal yaitu dari pihak administrasi bank yang terlambat memproses pencairan dana dikarenakan gangguan server di bank atau kurangnya pelayanan.

\section{Faktor Pendukung Penerapan Transaksi Non Tunai}

Dari hasil wawancara dengan pegawai pengelola Keuangan Daerah tentang faktor pendukung penerapan transaksi non tunai yakni dukungan teknologi yang sangat memadai, sarana dan prasaran pendukung yang sangat lengkap serta kemudahan jaringan internet. Selain itu, penggunaan transaksi non tunai juga direspon positif oleh para pegawai pengelola Keuangan Daerah, setiap 
Pegawai sudah memiliki rekening, kartu ATM serta m-banking dan telepon genggam berbasis android sehingga semakin memudahkan dalam penggunaan transaksi non tunai.

\section{KESIMPULAN DAN SARAN}

\section{A. Kesimpulan}

Penerapan transaksi non tunai dalam pengelolaan keuangan daerah pada sekretariat daerah Kota Metro Provinsi Lampung, memberikan banyak manfaat transaksi menjadi sangat efisien dan juga efektif. Keuntungan penerapan sistem transaksi non tunai yaitu, penggunaan aliran dana seluruh transaksi dapat ditelusuri sehingga lebih akuntabel, dikarenakan seluruh transaksi didukung dengan bukti yang sah; bendahara tidak harus memegang uang tunai dengan berbagai resiko kejahatan, kehilangan, dan kesalahan hitung; menghindari penyalahgunaan keuangan di perangkat daerah; penggunaan anggaran lebih efisien dan arus keluar masuk kas lebih terkontrol; meningkatkan pengendalian internal pengelolaan kas; dan mempermudah bendahara penerimaan penagihan. Transaksi non-tunai cenderung lebih hemat biaya apabila dibandingkan penggunaan transaksi tunai dengan uang kartal, alias uang kertas maupun uang logam. Mempercepat pelaksanaan tutup buku serta pelaporan keuangan dan dijamin kehandalannya.

\section{B. Saran}

1. Perlu dibuat aturan atau prosedur mengenai penerapan sistem transaksi non tunai ini, agar tujuan penerapan sistem transaksi non tunai ini bisa terlaksana dengan maksimal.
2. Sekretariat daerah Kota Metro dapat melakukan pengendalian internal pada pengelolaan keuangan dengan meningkatkan pengawasan dan pengecekan kelengkapan berkas dalam proses administrasi pencairan dana sehari sebelum tanggal pencairan dana atau mentransfer dana. Dengan melakukan pengendalian internal dapat meningkatkan kinerja keuangan dalam pengelolaan keuangan.

\section{DAFTAR PUSTAKA}

Anwar, P.M. (2001). Manajemen Sumber Daya Manusia Perusahaan. Bandung: PT. Remaja Rosdakarya.

Anwar, P.M. (2004). Manajemen Sumber Daya Manusia Perusahaan (Cetakan Ketiga). Bandung: PT. Remaja Rosdakarya.

Ardika, S. (2014). Pengaruh Upah dan Pengalaman Kerja terhadap Produktivitas Karyawan Kerajinan Ukiran Kabupaten Subang. Trikonomika, 13(1), $91-100$.

Arikunto. (2002). Prosedur Penelitian Suatu Pendekatan Praktik. Jakarta: PT Rineka Cipta.

Burhan, N., dkk. (2004). Statistik Terapan untuk Penelitian Ilmu-ilmu Sosial. Yogyakarta: Gadjah Mada University Press.

Dwiyanto. (2008). Mewujudkan Good Governance melalui Pelayanan Publik, cet. III. Yogyakarta: Gajah Mada University Press.

Ghozali, I. (2009). Aplikasi Analisis Multivariate dengan Program SPSS. Semarang: UNDIP.

Hadari, N. (2005). Penelitian Terapan. Yogyakarta: Gajah Mada University.

Hamid, P. (2011). Metode Penelitian Kualitatif. Bandung: Alfabet.

Keputusan Kepala Badan Kepegawaian Negara Nomor 43/Kep/2001. 
Keputusan Kepala Badan Kepegawaian Negara Nomor 46a Tahun 2003 tentang Pedoman Penyusunan Standar Kompetensi Jabatan Struktural Pegawai Negeri Sipil.

Moeheriono. (2009). Pengukuran Kinerja Berbasis Kompetensi: Competency Based Human Resource Management. Jakarta: Ghalia Indonesia.

Mohamad, M. (2017). Menata Pengembangan Karier Sumber Daya Manusia Organisasi. Jurnal Ilmiah Universitas Batanghari Jambi, 17(1).

Moleong, L. (2002). Metodologi Penelitian Kualitatif. Bandung: PT. Remaja Rosdakarya.

Muhammad, M. (2015). Analisis Pengembangan Karir Pegawai Pada Kantor Dinas Pendapatan Daerah Provinsi Sulawesi Tengah. e-Jurnal Katalogis, 3(12), 142 - 149.

Muis, M., \& Sidik, P.S. (2009). Metodologi Penelitian Ekonomi dan Bisnis. Yogyakarta: Graha Ilmu.

Nawawi, H. (2008). Manajemen Sumber Daya Manusia untuk Bisnis yang Kompetitif. Yogyakarta: Gadjah Mada Univesity Press.

Peraturan daerah Nomor 22 tahun 2007 tentang TUPOKSI Badan Kepegawaian dan Diklat Daerah Lampung Timur.

Prawirosentono. (2008). Manajemen Sumber Daya Manusia Kebijakan Kinerja Karyawan. Yogyakarta: BPFE.

Pusat Kajian dan Pendidikan dan Pelatihan III Aparatur 2005 dan 2008.

Pusat Kajian Kinerja Sumber Daya Aparatur Lembaga Administrasi Negara 2006.

Rivai. (2008). Kepemimpinan dan Perilaku Organisasi, Edisi Ketiga. Jakarta: Rajawali Pers.
Siagian. (2002). Manajemen Sumber Daya Manusia Cetakan Kesembilan. Jakarta: Penerbit Bumi Aksara.

Siagian, S. (2007). Manajemen Sumber Daya Manusia. Jakarta: PT. Bumi Aksara.

Sinambela. (2016). Manajemen Sumber Daya Manusia. Jakarta: PT Bumi Aksara.

Sugiyono. (2003). Prosedur Penelitian Suatu Pendekatan Praktik. Jakarta: Rineka Cipta.

Suharto. (2017). Mediasi Kualitas Pelayanan Atas Kemampuan Manajerial Dan Komitmen Organisasi Terhadap Kepuasan Nasabah. Derivatif: Jurnal Manajemen, 11(1), $61-75$.

Sutrisno. (2010). Manajemen Sumber Daya Manusia Edisi Pertama Cetakan Kedua. Jakarta: Kencana Prenada Media Group.

Tjiptono, F. (2003). Total Quality Service. Yogyakarta: Andi Offset.

Usmara. (2010). Strategi Baru Manajemen Pemasaran. Jakarta: Amara Books.

Wahyu, R., Muhaamad, A.H., \& Taufik, W.H. (2013). Prosedur Penerbitan Surat Izin Belajar Pegawai Negeri Sipil di Lingkungan Pemerintahan Deli Serdang. Jurnal Ilmu Pemerintahan dan Sosial Politik, 1(2), $161-175$. 